\title{
The Intersection of AB705 on Race and Individuals With Developmental Disabilities: Striving for Student Equity Through Eliminating Developmental Education
}

\author{
Elizabeth A. Craigg \\ Claremont Graduate University, Claremont, United States
}

\begin{abstract}
African-American men are more likely to attend community colleges. On October 13, 2017, the Governor of California passed AB705 that was set to be implemented on January 1, 2018, but all California community colleges must be compliant by Fall 2019. The intent of AB705 was to statistically improve community college completion and/or transfer rates to a four-year institution through eliminating developmental English (and Math) courses since the testing placement into Math and English was arbitrary. Organizations and proponents of the bill emphasize AB705 creates a level of equity amongst minority students and white students that some would even call its implementation eliminates the college achievement gap. The passage, and now inevitable implementation, revealed three things: 1 . There was an assumption that reading and writing was of one discipline; 2 . There was a profession of developmental education built on the backs of a majority of black and brown students-educational inequity amongst white and black students; and 3. The very existence of developmental education is rooted in implied bias. California Community College Faculty is still 70\% White, while the students who are in these developmental classes are over 70\% Black and Latino male. This paper is an evaluation of California's AB705 Law that will be utilized as an open-discussion of the following: (a) the educational conditions that led to the implementation of AB705; (b) the description of AB705; (c) how colleges have interpreted and implemented AB705; (d) consider the intersection of race and students with disabilities; and (e) the recommendations for implementing AB705. Thus, the overall premise for the paper would be for community colleges need to re-create college-transfer-level English with a growth mindset.
\end{abstract}

Keywords: AB705, community college, California, developmental courses, African-Americans, education, black, men

\section{Introduction}

As the author sat in a meeting exploring what we plan on doing as a department to handle the changes AB705 was going to bring to our course offerings, one of his peers stated, "We are finally going to give African-American students a chance that they didn’t have.” Being the only African-American faculty member who participates in the English department professional development activities, the author asked a question, "What were we doing before?” The meeting became awkwardly silent. Like most community colleges around

Craigg Walker, Elizabeth, MP.A., M.A., Ph.D. (ABD), research assistant, School of Educational Studies, and Emeritus, Faculty Fellow, Preparing Future Faculty, Claremont Graduate University. 
California, most of the faculty is white and female. Most minority faculty members, like himself/herself, are adjuncts that teach developmental courses if they teach in the English and Math departments. At this particular community college, there are no African-American full-time faculty members within the English department, while there are a few African-American adjunct instructors.

After the author's colleagues looked around at each other, one of his colleagues eventually responded to my question, by asking him to repeat his question. The author obliged, "If we are giving African-American students 'a chance' with AB705, then what were we doing before AB705?” Many of his colleagues looked around at each other and continued onward with the discussion. His question was never addressed, but it is in this space that the author hopes to address developmental education, as the community college system around the country have created an industry off the backs of Black and Brown students. Yet, this paper is setting a framework of what the English curriculum should look like in the age of AB705 within California's Community College System.

Even though African-Americans make up 6\% of California's 39 million populations, the percent of African-Americans who attend one of the University of California campuses is $3 \%$, while the California State University is slightly higher with $4 \%$ (Gordon, 2018). African-American students in California are more highly concentrated at the community colleges with 6\%, and they find themselves much more likely to take at least one developmental course in their community college career. In fact, the community college system also has the highest level of non-traditional students, where the California Community College Chancellor's Office approximates that non-traditional students make up roughly $42 \%$ of the collective enrollment within the California Community College System. The Public Policy Institute of California reviews that $87 \%$ of all African-American students who attend community colleges will find themselves taking at least one developmental course (Bliss \& Pottinger, 2016). The faculty at the community college are largely white and female, as $61 \%$ of the tenured track faculty is white and $54 \%$ of the tenured faculty is female (Gordon, 2018). The intersection happens in developmental education, where the faculty is largely white and female and the students are largely Black and Latino.

This paper will define developmental education courses, and then this paper explores the problems of developmental courses that have led to AB705. The policy of AB705 was not created in a vacuum, thus, it is important to explore the meaning of the legislation in order to determine the predicted outcomes. Finally, the paper presents suggestions for community colleges who are struggling to improve developmental education, yet this paper's focus will be on English departments.

\section{Understanding Developmental Courses}

Developmental courses have been incorporated within higher education since Harvard College opened its doors. Harvard College first allowed developmental courses to help students learn Latin in order to complete coursework since most of the courses were taught in Latin. As college curriculum evolved, developmental courses increased, but these courses were used to compensate the deficiencies students have in Math and English. In California, the number of developmental courses ballooned to dominate the course offerings. These courses can make up over $60 \%$ of all course offerings at California community colleges every single semester. Some estimate that at least four out of every 10 community college students take at least one developmental course, while others estimate that the number is much higher, such as six out of every 10 community college students take a developmental course. Amongst the African-American community, it is eight out of every 10 
community college students that will take at least one developmental course (Bliss \& Pottinger, 2016). When reviewing community college catalogs around California as late as the 2018/2019 school years, some California community colleges have as few as two developmental college courses below transfer-level courses in either Math or English, while other community colleges have as many as six developmental courses below transfer-level courses in Math or English. In theory, a student could take up to six courses in Math and six courses in English "before" reaching transfer-level English and Math courses. Thus, a student could spend years in developmental courses if they test below transfer-level in Math and/or English.

Developmental English curriculum is designed to be rudimentary work, as it focuses on a formula of how to write, check grammar and punctuation, etc. Bailey, Jaggars, and Jenkins (2016) asserted "developmental courses are not designed to build the type of reading, writing, and quantitative skills necessary for success in disciplinary coursework, such as assessing an argument, writing research papers, or understanding statistical tables and figures" (pp. 128-129). Thus, the developmental curriculum builds students to move into the next English course, but it does not provide the skills that lay the foundation for other college courses. Even further, students are even unaware of how to apply the skills they learned in these courses to other foundational courses, as Bailey et al. (2016) described developmental students lack "a complex task requiring meta-cognitive abilities," yet there is a concession that "college-ready" students also lack these skills.

Critics of developmental courses have pointed out a few problems. Even if they are useful in preparing students to handle college coursework, students who spend more time in developmental courses are much more likely to drop out of college. In fact, the Education Commission of the States, Center for the Analysis of Postsecondary Readiness, states that between 19\%-29\% of all students who take developmental courses will move on to completion, and eventually, graduate. The Community College Research Center further states that $30 \%$ of the students who even test into developmental education do not even enroll into college after seeing the number of courses they would have to take. These findings further support Dougherty's (1994) work on how community colleges are truly a democratic institution, but it also tempers the desire to persist in earning a four-year degree. In The Contradictory College, Dougherty (1994) named this as the "cooling-off effect." Developmental education strengthens this effect.

In addition to the high drop-out rate, African-American students are placed in developmental courses at a much higher rate than any other student. According to the Education Commission of the States, Center for the Analysis of Postsecondary Readiness, 78\% of African-American students are placed in developmental, whereas $64 \%$ of white students are placed in the same courses. There are systemic K-12 educational gaps between white and black students, but at the community college, every student enters at the same location, with supposedly, the same start. All students must take a placement exam, in which most community colleges utilize Accuplacer for the exam. These exams have internal bias, as the English exams utilize cultural reference and American historical inference within the reading comprehension questions. In addition, both Math and English assessment tests focus more on the deficiencies of a person and not on what students know (Bailey \& Cho, 2010). Therefore, many students are incorrectly placed in developmental coursework, yet students feel that once they have taken the exam, then they are referred to the counselor. Bailey et al. (2016) demonstrated the gross misplacement being, "among students who took the reading and writing placement tests, 29\% were severely under placed and 5\% were severely over placed” (p. 125). Students are unaware of the miscalculation of the tests, as these students feel that they must take the classes they were placed via the Accuplacer exam. In fact, community colleges placed an institutional barrier with students having a registration hold placed on their 
account until they speak to a counselor that places them into the class that was recommended from Accuplacer. Students were unaware that there was a choice in taking the recommended course, as it was on their educational plan and there was not another course alternative.

Finally, developmental courses prolong completing transfer-level courses. In fact, these courses cause community college students to have excess credits since these courses do not transfer. Fink, Jenkins, Kopko, and Ran (2018) found that all students who transfer struggle with having $20 \%$ of their units not transferring. Many of these students were on financial aid at the community college level, which means that these students where utilizing financial aid for a longer period of time. Eventually, community college students run out of financial aid in the final years of their bachelor degree program.

Within a field study of non-traditional transfer students at two California community colleges (El Camino College and Compton College), Anthony Onwuegbuzia (2019) interviewed 10 students to examine the financial impact these students had after spending an extended amount of time at their respective community colleges. Both of the institutions have over 50\% Latino student population with an African-American population being $25 \%$ at Compton College and $14 \%$ at El Camino College. Out of the 10 students interviewed, six of the students spent at least one class in developmental courses, along with them having spent more than four-years at the community college.

Developmental courses are expensive for the State of California and for students. Developmental courses are expensive for the students and the college, as the annual cost of developmental courses across the United States is around $\$ 4$ billion (Bailey et al., 2016, p. 121). Specifically, community colleges pay $\$ 5,000$ more per developmental students who complete a degree over the course of five years (Bailey et al., 2016, p. 177). When evaluating the numbers of the cost per student over the course of five years, more money is spent on college-ready students, but this is only because fewer developmental students actually persist in school over five years. Therefore, less money is spent on developmental students. Fewer developmental students complete a degree program; while more money is spent on them than college-ready students.

\section{Defining AB705 Legislation}

The premise of AB705 is to minimize and limit developmental education courses for one-year. The California Community College Chancellor's Office states "The goal of AB705 is to ensure that students are not placed into remedial courses that may delay or deter their educational progress unless evidence suggests they are highly unlikely to succeed in the college-level courses." Class placement is based on various measures, such as high school grade point average and high school coursework, and as of September 2019, the Accuplacer placement exam is no longer utilized. Any student who takes developmental courses has only one year to complete remediation before enrolling into transfer-level courses. English as a second language (ESL) students can receive additional support, if necessary.

Out of this legislation, there is an implementation of choice, as students have always had a choice to take developmental courses, yet colleges did not follow this policy. The practice of taking a placement exam and enrolling in the courses that the test recommended was just that-a suggestion. It was not mandatory for students to enroll in developmental courses. Counseling students are now focused on making suggestions on what classes to take, which now gives each student the power over their own educational plan.

The danger for students derives from the federal requirement that students must maintain their ability to have satisfactory academic progress in their degree program. Under this program, students need to maintain a 
2.0 GPA along with maintaining passing enough classes (C, D, F, and W's are all included in the calculation) to be financial aid eligible (The FastWeb Team, 2018). According to California Law 55040 (b) (1), 55041, college students are only able to take one class three times at the same campus, which will affect students if they incorrectly place themselves in the wrong English course. Students will be forced to transfer to another campus in order to complete their requirements if they are unable to pass the English course. Thus, colleges are eager to find additional resources to ensure completion rates, yet the California Community College Chancellor is warning the community colleges to prepare for a large reduction in community college students as the California Acceleration Project (CAP) and the Public Policy Institute of California assert that " $44 \%$ of students in remedial English” are likely to pass a transfer-level English course (Zinshteyn, 2018). Even as the statistic of $44 \%$ is rather high, one must ask a question, "What happens to the other $56 \%$ who are likely to not pass transfer-level English?”

\section{Community College's Outcome for Developmental Education-Acceleration}

To assess the success of developmental education, policy institutes and major supporters of acceleration, such as the CAP turns its focus on the high student drop-out rates. Since three out of every four students who are placed in developmental education courses drop out of college before reaching college-level courses, scholars and policy makers conclude that these courses are not working. Accelerated Learning Programs have been generated around the country, such as the one in Baltimore County, in which a student enrolls in a college-level course along with a co-requisite course for Math and English to help these students make it through the college-level courses (Bailey \& Jaggars, 2016). This co-requisite model has been adapted for many California community colleges.

CAP has been on the forefront of demonstrating the co-requisite model of English and Math courses before AB705 passed. Now that AB705 has been implemented, CAP has been providing workshops around the State of California with faculty on how to develop curriculum and teaching practices for the newly modified English and Math courses. In June of 2018, the opening preliminary session of a CAP conference held in Riverside, California attempted to address the nervousness of many English and Math faculty around Southern California. A full-time reading professor raised her hand to ask the question that many full-time reading professors have been wanting to ask, "What will happen to my job when AB705 becomes into effect fully in the Fall 2019?” The speaker had a pregnant pause and simply replied, “That is up to your institution. The institution can write the curriculum for the new classes in a way to help you keep your job (reading faculty to stay qualified to teach these courses)." A long sigh erupted over the English reading faculty, because they are well aware that this is not happening. In fact, the speaker made another revelation, "The authors of the AB705

legislation thought that English writing and English reading was just one thing. They did not know that reading and writing were different." If faculty did not feel worse, then that statement sealed the deep concerns people had about AB705.

As faculty discussed AB705 throughout the conference, the most common question was "What is your campus doing?" The first response was about the elimination of classes that has led to many campuses eliminating jobs and departments. Adjunct English faculty has decreased at every single community college with California. Full-time reading faculties have been asked to re-tool and earn a master in English literature or in rhetoric composition. Faculty who have been teaching reading for years are now forced to walk away from their discipline that some districts are paying for the degree or the faculty has to pay for it themselves. In either 
case, campuses have sent out memos urging faculty to complete the requirements to keep their job by Fall 2019; they have exactly one year to complete the stated requirements. With tremendous uncertainty for their employment, many faculty members are now forced to develop how to merge their discipline with English writing-transfer level courses.

Citrus College was the first community college that has eliminated all developmental English courses. The English courses have changed in the following manner (Henson, 2019):

1. They are now four unit courses instead of three unit courses;

2. The class size decreased from 30 to 25 students;

3. added a one-unit co-requisite course;

4. Tutors are in every co-requisite course;

5. changed the reading criteria to non-fiction, fiction, media, and other scholarly texts.

Edgecombe and Bickerstaff (2018) recommended academic support within the classroom, such as in-class tutoring, yet having a co-requisite is not suggested. The results are all students have completed English composition courses at a higher rate (from 53\% to 64\%) and African-American students have a higher completion rate (40\% to $53 \%$ ) and Hispanic students have a higher completion rate (50\% to 63\%) (Henson, 2019). The analysis of these numbers has people stating the achievement gap between minority and white students is decreasing.

Irvine Valley College (IVC) and College of Redwoods have taken a different approach than Citrus College. IVC has allowed students to self-guide their placement within courses. This was done through eliminating the developmental courses as an option for the students to place themselves. The only classes they are able to see are transfer-level classes. Even though developmental courses have not been completely eliminated, the courses have removed from their academic placement. The reasoning behind this practice is trying to strengthen the academic confidence through allowing students to make more informed decisions (Edgecombe \& Bickerstaff, 2018). Similarly, the College of the Redwoods did not select a co-requisite model. Rather, they are providing workshops in an accelerated manner to help students become more equipped with the topic. Thus, they could help remediate any academic deficiency in short periods of time. Edgecombe and Bickerstaff (2018) highly suggested this method of short remediation sessions to strengthen writing and reading skills.

\section{The Overlooked Population-Students With Disabilities}

Race is a prominent discussion about students who are directly impacted from the AB705 implementation. The intersection of race and students with disabilities is largely discussed, as African-Americans are one of the three highly represented groups labeled with a disability within the K-12 system. Nationwide, African-Americans only make up around $17 \%$ of the K-12 system, while they represent $26 \%$ of the Special Education departments (Banks, 2017). In California, 12\% of all students enrolled in K-12 schools are placed in special education. Out of this group, 8.6\% are Black, being the third largest group ("Special Education Enrollment, by Race/Ethnicity”, 2016). There are fewer Blacks within the State of California, which allows them to be labeled as being an overrepresented group in Special Education. Essentially, for every 100 students who are enrolled in a California school, there are only six Black students. Of those six Black students, and then there would be two Black students who are placed within special education.

There are more African-American boys who are placed within these courses. Some of the causes for labeling is African-American students fall behind other students, as in California, (on average) for every white 
student who lost 31 school days due to suspension; whereas, African-American students lost 82 days (Romney, 2018). Black students tend to be caught misbehaving more than white students for the same offense and Black students are much more likely to be punished harsher for the same offense, which is why Black students lose more time being in school. These students are continually placed within special education, when they are displaying behavior that resembles a disability when it could be just students who are behind their peers.

Monique W. Morris (2016) asserted that Black girls are much more likely to be in special education not because they are properly labeled, but due to the amount of physical, sexual, and emotional trauma they may have experienced, they were not as privy to the same educational experience as others. They are simply behind their counterpart, but being placed in special education during high school leads them to need more services when they enter into community colleges. With many Black girls and boys being subjected to overly punished in public K-12 schools, the lasting effects is a broken education during their formative years. Banks (2017) further demonstrated Black male students are isolated from the rest of the academic curriculum along with these students experiencing a high level of implicit bias and micro-aggressions that happen within the classroom. With these experiences, these students are more likely going to attend the local community college because it is an open-access institution.

When students attend the community college, it is their responsibility to self-identify. In fact, professors are not permitted to tell a student that they need to go to the disability office even if it is a visible disability. It is the student's responsibility to ask for help. Thus, the data collected from the California Community Colleges Chancellor's Office, demonstrate that students with disabilities make up about $4 \%$ of the population. These numbers will never be accurate, as there are students who make the decision to not identify with a disability. Even amongst those who self-identify, individuals with a disability are over-represented in developmental courses. In fact, based on representation, the percentages of those in developmental classes are double the amount of those in transfer-level college courses. Yet, these students tend to be overlooked, as they are still only $8.4 \%$ of the population who are taking developmental courses (Skinner, 2016). In fact, more students with a disability are enrolled in basic skills over any other types of coursework, such as transfer-level, vocational, or work-preparation courses (Skinner, 2016). An even more alarming number is there is a high percent of students with disabilities (10.7\%) who are full-time students with a course load of only developmental/basic skills courses (Skinner, 2016). There could be a number of reasons for the decision to continue to take basic skills or developmental coursework above all other types of classes, but one thing is evident, students with disabilities will be greatly affected with a diminishing number of developmental courses available due to AB705.

In what Dougherty (1994) has called the most democratic institution, the community college, we must ask that in the wake of AB705, what will happen to the students with disabilities if the courses that they are most-likely to attend will be eliminated? We are fully aware that compared to the students without a disability, students who have self-identified with a disability and are connected with the disability student programs and services department on their campus have a much higher retention rate. Students with a disability have a retention rate of $81.9 \%$, whereas students without a disability have a significantly lower retention rate of $69.9 \%$ (Skinner, 2016). In fact, these very same students are much more likely to complete the courses and move on to degree attainment. These numbers of $11.8 \%$ of students with disabilities are likely to complete their degree after starting in developmental/basic skills contradict the number of students who do not have a disability being able to complete a degree after starting in developmental/basic skills classes with it being just $8.5 \%$. Even 
though developmental classes are hindering the completion of students who do not have a disability, these courses are helping those with a disability.

\section{Recommendations}

\section{Create a Shorter Pathway to Transfer-Level Courses With Fewer Developmental Courses}

Developmental course should not be eliminated. AB705 still allows developmental courses to be taught, but they have one year to remediate before taking transfer-level courses. Additional courses should be moved over to adult education. Yet, these adult education courses need to be entirely free and easy to enroll. There should not be a separate application for adult education than for regular (for-credit) courses.

\section{Re-Evaluate the Student Learning Outcomes for Transfer-Level English Courses}

Many community colleges are adding more hours to the transfer-level English courses, when we really need to re-evaluate the student learning outcomes of these courses. We need to dig deep and ask a question about the introductory English course: Are we teaching them to read and write for college-level coursework or are we trying to teach to our discipline of English? We could say yes to both, but then we would need to stop being so discipline specific. If we are helping students read and write for all college-level coursework, then we should teach students how to not only write in MLA format, but in APA format.

Quite often, we have professors from other disciplines lament on how students do not know how to write. There is an assumption that taking English classes should be enough to help students write fluently, yet when that does not happen, professors begin to wonder what was happening in English classes. Cox (2009) described a psychology professor who reflects on how students do not seem to appear to know how to write well when entering into the class. Bailey et al. (2016) furthered this assertion with college-ready students do poorly "in other key introductory course, including History of Western Civilization (where the failure rate of eventual dropouts was 18\%), Introduction to Business (18\%), Principles of Accounting I (23\%), and Beginning Spanish I (18\%)” (p. 129). We have selected English to be one of the two subjects that are remediated, because English is a foundational course, yet English cannot be foundational if we are designing the course only for students who may "stay" in the English major. Thus, the author poses the question, "If the student does not learn how to write well in their respected disciplines in English class,” then "Where should they learn it?”

The first English transfer-level course should be to teach students how to write, grammatically correct essays of different types. They should be introduced to the different types of formatting, such as MLA, APA, and Chicago. The class should not have a long-text because there should be different types of readings, such as non-fictional articles, such as academic and news articles.

\section{Do not Have a Mandatory Lab Component to English Courses}

In order to write better, you have to write more. Yet, having five hour classes is excessive. There has been encouragement for faculty to divide up the classes into units and provide students more interactive class sessions, but having two three-hour courses or three two-hour courses or two two-hour courses combined with two one-hour courses are all excessive. If a student has a Math and English course, then they would actually only be able to take fewer classes each semester.

As a professor, we struggle with having students attend all of the classes and/or leaving early. Students are not interested in coming more than twice a week for a 16-week semester. Also, students are not interested in staying for a longer period of time for two times per week. Writing and reading for three hours is exhausting for 
the students and the faculty member. There are fewer students who want to take a course with a laboratory class; therefore, students are much more interested in enrolling into a transfer-level English course.

AB705 is trying to remove developmental classes, but it is also a time to remove a developmental mindset. We, as professors, are holding onto what Dweck would call the fixed mindset that students should not be trusted to write well and comprehend reading assignments; therefore, adding more instruction time is the answer. More time in the classroom is not the answer. Redefining the purpose of the Introductory English-level coursework to revise the Student Learning Outcomes with more instructor support is the answer.

\section{Conduct Mandatory Professional Development for Faculty}

How do we know that our students have learned? The answer to this question varies, as some professors will refer back to the syllabus on the days that the subject was covered, while others will refer to the exams that demonstrate the test scores are indicative of learning happening. Preparing Future Faculty (PFF) at Claremont Graduate University has a different approach to identify when students learn. PFF has generated professional development workshops for future faculty, in which instruction should be student-centered. Therefore, good instruction has moments of checking for understanding to identify if learning is taking place. Waiting for exam scores is not an indication that learning is happening because an exam could be too late of an indicator, and exams could only show short-term memory and not true life-long learning.

AB705 is trying to disrupt the current curriculum. Therefore, we need to disrupt how we interpret learning. This would also require a disruption to instruction. There are three different areas of professional development that could strengthen college instruction: inclusive pedagogy, teaching practices for students with a developmental disability, and acknowledging implicit bias in teaching and grading practices.

\section{Inclusive Pedagogy}

When diversity is defined, many people suggest race and gender. Yet, diversity means a surplus of things: sexual identity, origin of birth or location a person is raised, socioeconomic status, and developmental and/or physical disabilities. All of these differences, and other categories, are things that we need to evaluate and treasure as diversity in the classroom. Thus, our professors need to find a way to include a wide variety of voices to make classrooms a safe and brave spaces for all students to be able to learn, share, develop, and reflect throughout the semester. This would first start with the simple strategies of trying to not only know the students' names, but to find out something about them.

The importance of knowing your students is to create a community that would be built on trust and care. When students know you trust and care for them, then they are willing to persist in the coursework through doing the assignments and completing the class. Our goal should be to utilize the knowledge we have of our students to create meaningful curriculum that has lessons to match with the needs and interests of our students. The assignments and course schedule should shift based on our ability to engage the student's interests. To truly have inclusive pedagogy, the professor must be agile and transparent with the purpose of the course changes.

\section{Teaching Practices for Students With a Developmental Disability}

Developmental classes tend to have a higher number of students with a disability. Even though students have the ability to receive resources for assistance with completing their coursework, professors are not assisted with how to teach a student with a disability. Physical disabilities are much easier to address than developmental disabilities for the basic reason that physical disabilities are visible to the eye. Developmental or cognitive disabilities are able to be recognized if a professor is taught some of the basic signs of identifying 
disabilities. A professor should not be in the business of diagnosing a student, but recognizing identifying markers would be useful in understanding the student's needs in order to best determine teaching practices.

Professional development becomes necessary in tailoring pedagogical practices to best help the needs of the students with a cognitive disability. Designing a more inclusive classroom becomes necessary and planned when considering there will be more students with developmental disabilities entering into transfer-level coursework. Preparing Future Faculty utilizes the principle of Universal Design for Learning when designing lesson plans implemented within the classroom. When you create a classroom space that considers students with varying learning preferences and learning disabilities/abilities, then everyone benefits from learning. It calls for the professor to think about all types of learners within the classroom, which would require intentional design.

When considering all types of learners, a professor should be equipped with knowing or identifying some of the major disabilities in order to utilize agility in reaching the needs of these students. A professor should not diagnose a student, but a professor should identify the student's needs will help build community and increase student success. One major necessity is having patience with your students. For example, there are some students with Autism who have outbursts in class. They are unable to detect how other people may feel about their comments in class, which means that their comments during a discussion can be very distracting. Giving them space to contribute while also providing them with guided assistance of correct and incorrect speech is permitting them an equitable college experience to their peers. Another example would be realizing that some of your students may have a social disability is useful when considering assigned group work. Yes, professors want greater control of their classroom, but is assigning people to groups more important than creating a warmer classroom for everyone? You can always guide people, but to force people to be in certain groups could increase anxiety for students that would hinder their participation. These are just a few examples, as community college instructors need to be well-equipped to generate lessons that would teach and include students with disabilities.

\section{Acknowledging Implicit Bias in Teaching and Grading Practices}

Everyone has a personal experience, a history, that spills over into our everyday lives. We interact with people based on our life history, which means that we all carry some level of implicit bias. It is important to be aware of our bias, so that we can identify the bias when it arises in our teaching practices and our interactions with our students. The effects of ignoring our own bias results in furthering the educational inequality amongst the various races, and the greatest hard would be to underestimate students' potential (Garcia, 2018). With many community colleges in California not having a single full-time African-American professor within the English department, the necessity to have more teachers training on how to manage implicit bias becomes vital for student access.

\section{Future Study}

This paper was just the beginning of understanding what AB705 means to the community college and the students. As the author has discussed, it is altering the community college landscape to make transfer level English and Math courses more accessible to students. This review of understanding what other campuses are doing to address the needs of students along with recommendations on how AB705 should continue to radicalize college English instruction is the initial start in evaluating the community college. The future study 
will come from empirical studies on AB705. We do not know the effects this policy has on student retention, student attrition, college staffing, discipline restructuring, course design, class schedule, and the overall community college campuses. All of these areas need to be evaluated in subsequent papers. We, as professors and scholars, have a responsibility to continue to evaluate academic shifts in order to improve educational opportunities for every student.

\section{Conclusion}

The State of California has been stressing the necessity of community college to become more accountable to ensuring student success. The goal was for being able to document the necessity for the State of California to spend $54 \%$ of its state budget on K-13 (community colleges are included in the K-12 budget). AB705 was to increase accountability through minimizing the number of developmental courses students will complete. Since all stakeholders were not involved in passing the AB705 policy, community colleges are forced to tackle understanding how to implement it through innovation. Community colleges are creating vibrant options, but we need to also consider professional development for our English faculty to be effective within the classrooms across the state.

\section{References}

AB705 (Irwin)-Seymour-Campbell Student Success Act of 2012: Assessment. Chapter 745, Statues of 2017. California $\begin{array}{llll}\text { Community Colleges Chancellor's } & \text { Office. }\end{array}$ from http://www.californiacommunitycolleges.cccco.edu/Portals/0/GovRelations/Enacted-Bills/ab-705-summary.pdf

Bailey, T., \& Jaggars, S. S. (2016, June 2). When college students start behind. In The Century Foundation. Retrieved from https://tcf.org/content/report/college-students-start-behind/?agreed=1

Bailey, T., Jaggars, S. S., \& Jenkins, D. (2016). Redesigning America's community colleges. Massachusetts: President and Fellows of Harvard College.

Bailey, T., \& Cho, S. W. (2010). Developmental education in community colleges. Community College Research Center. Retrieved from https://www2.ed.gov/PDFDocs/college-completion/07-developmental-education-in-community-colleges.pdf

Banks, J. (2017, February 22). These people are never going to stop labeling me: Educational experiences of African American male students labeled with learning disabilities. Equity and Excellence in Education, 50(1), 96-107.

Bliss, S., \& Pottinger, L. (2016, November 9). Remedial courses in community colleges are major hurdle to success. Public Policy Institute of California. Retrieved from https://www.ppic.org/press-release/remedial-courses-in-community-colleges-are-major-hurdle-to-success/

California Accelerated Project. (2020). Retrieved from https://accelerationproject.org/

Cox, R. D. (2009). The college fear factor. Cambridge, Massachusetts: Harvard University Press.

Credit Course Repetition Guidelines. (2013, November). California Community Colleges Chancellor's Office. Retrieved from https://extranet.cccco.edu/Portals/1/AA/Credit/2013Files/CreditCourseRepetitionGuidelinesFinal.pdf

Dougherty, K. J. (1994). The contradictory college: The conflicting origins, impacts, and futures of the community college. New York: SUNY Press.

Edgecombe, N., \& Susan, B. (2018, April). Addressing academic under preparedness in service of college completion. Texas Education Review, 6(1), 75-83. Retrieved from https://ccrc.tc.columbia.edu/publications/addressing-academic-underpreparedness-college-completion.html

Fink, J., Jenkins, D., Kopko, E., \& Ran, F. X. T. (2018, February). Using data mining to explore why community college transfer students earn bachelor's degrees with excess credits. In Community College Research Center, Teachers College, Columbia University.

Retrieved from https://ccrc.tc.columbia.edu/media/k2/attachments/using-data-mining-explore-why-community-college-transfer-student s-earn-bachelors-degrees-excess-credits.pdf

Ganga, E., Mazzariello, A., \& Edgecombe, N. (2018, February). Developmental education: An introduction for policymakers. In Education Commission of the States, Center for the Analysis of Postsecondary Readiness. Retrieved 
from https://www.ecs.org/wp-content/uploads/Developmental-Education_An-Introduction-for-Policymakers.pdf

Garcia, M. (2018, July 25). Why teachers must fight their own implicit biases. In Education Week Teacher. Retrieved from https://www.edweek.org/tm/articles/2018/07/25/why-teachers-must-fight-implicit-biases.html

Gordon, L. (2018, March 5). Whites dominate California college faculties while students are more diverse, study shows. EdSource. Retrieved

from https://edsource.org/2018/whites-dominate-california-college-faculties-while-students-are-more-diverse-study-shows/5 94268

Henson, L. (2019, February). Remedial English courses eliminated, all students begin in college composition. The Capacity Gazette. Retrieved from https://accelerationproject.org/Portals/0/Documents/Cap_Gazette_2019_v5_Web.pdf

Huntsman, H. (2019, February). Do no harm guided self-placement. The Capacity Gazette. Retrieved from https://accelerationproject.org/Portals/0/Documents/Cap_Gazette_2019_v5_Web.pdf

Huntsman, H. (2019, February). Open-access liberal arts math and other innovations. The Capacity Gazette. Retrieved from https://accelerationproject.org/Portals/0/Documents/Cap_Gazette_2019_v5_Web.pdf

Johnson, H. (2017, March). Just the facts: California's population. Public Policy Institute of California. Retrieved from https://www.ppic.org/publication/californias-population/

Morris, M. W. (2016). Pushout: The Criminalization of black girls in schools. New York: Westchester Publishing Services.

Onwuegbuzia, A. (2019). Financial literacy and the non-traditional community college transfer student: Realities of planning for transfer. In CC2PHD UCLA Symposium. Los Angeles California. Preparing Future Faculty, Claremont Graduate University. Retrieved from https://mycampus.cgu.edu/web/preparing-future-faculty/pff-home

Reynolds, T., Zupanick, C. E., \& Dombeck, M. (2019). Effective teaching methods for people with intellectual disabilities. MentalHelp.net.

Retrieved from https://www.mentalhelp.net/articles/effective-teaching-methods-for-people-with-intellectual-disabilities/

Romney, L. (2018, May 3). African-American students with disabilities suspended at disproportionately high rates. EdSource. Retrieved

from https://edsource.org/2018/african-american-students-with-disabilities-suspended-at-disproportionately-high-rates/59705 2

Skinner, E. E. (2016). Report on disabled student programs and services. California Community Colleges Chancellor's Office. Retrieved from http://californiacommunitycolleges.cccco.edu/Portals/0/Reports/2014-CCCCO-DSPS-Legi-Report-v2.pdf

The Fastweb Team. (2018, December 3). Students lose financial aid for failure to make satisfactory academic progress. FastWeb. Retrieved from https://www.fastweb.com/financial-aid/articles/students-lose-financial-aid-for-failure-to-make-satisfactoryacademic-progress

Zinshteyn, M. (2018, August 20). California community college urged to plan now for fewer students in remedial courses. EdSource.

Retrieved

from https://edsource.org/2018/california-community-colleges-urged-to-plan-now-for-fewer-students-in-remedial-courses/60 0905 